$6-1-2006$

\title{
The Chronic and Increasing Shortage of Fully Certified Teachers in Special and General Education
}

\author{
Erling E. Boe \\ University of Pennsylvania, boe@gse.upenn.edu \\ Lynne H. Cook \\ California State University
}

Follow this and additional works at: https://repository.upenn.edu/gse_pubs

\section{Recommended Citation}

Boe, E. E., \& Cook, L. H. (2006). The Chronic and Increasing Shortage of Fully Certified Teachers in Special and General Education. Retrieved from https://repository.upenn.edu/gse_pubs/147

(C2006 Council for Exceptional Children. The final, definitive version of this article has been published in the Journal for Exceptional Children, Volume 72, Issue 4, Summer 2006, pages 443-460. Printed with permission by the Council for Exceptional Children.

This paper is posted at ScholarlyCommons. https://repository.upenn.edu/gse_pubs/147

For more information, please contact repository@pobox.upenn.edu. 


\title{
The Chronic and Increasing Shortage of Fully Certified Teachers in Special and General Education
}

\author{
Abstract \\ This study addresses the chronic and increasing national shortage of fully certified special education \\ teachers (SETs) in comparison with general education teachers (GETs). The data sources were the \\ 1987-1988 through 1999-2000 Schools and Staffing Surveys and the Data Analysis System for special \\ education for school years 1987-1988 through 2001-2002. The study found that (a) the shortage of fully \\ certified SETs increased from $7.4 \%$ in $1993-1994$ to $12.2 \%$ in $2001-2002(2 \%-4 \%$ greater than the \\ shortage of fully certified GETs), (b) the number of additional fully certified SETs needed almost doubled \\ from 25,000 in 1993-1994 to 49,000 in 2001-2002, (c) the shortage of fully certified teachers was \\ exacerbated by entering teachers (only $44.4 \%$ of entering SETs were fully certified), and (d) only $53.1 \%$ of \\ first-time entering SETs with extensive teacher preparation were fully certified.

\section{Comments} \\ (C2006 Council for Exceptional Children. The final, definitive version of this article has been published in \\ the Journal for Exceptional Children, Volume 72, Issue 4, Summer 2006, pages 443-460. Printed with \\ permission by the Council for Exceptional Children.
}




\section{The Chronic and Increasing Shortage of Fully Certified Teachers in Special and General Education}

ERLING E. BOE

University of Pennsylvania

LYNNE H. COOK

California State University, Dominguez Hills

ABstract: This study addresses the chronic and increasing national shortage of fully certified special education teachers (SETS) in comparison with general education teachers (GETs). The data sources were the 1987-1988 through 1999-2000 Schools and Staffing Surveys and the Data Analysis System for special education for school years 1987-1988 through 2001-2002. The study found that (a) the shortage of fully certified SETs increased from $7.4 \%$ in 1993-1994 to $12.2 \%$ in 2001-2002 (2\%-4\% greater than the shortage of fully certified GETs), (b) the number of additional fully certified SETs needed almost doubled from 25,000 in 1993-1994 to 49,000 in 2001-2002, (c) the shortage of fully certified teachers was exacerbated by entering teachers (only $44.4 \%$ of entering SETs were fully certified), and (d) only $53.1 \%$ of first-time entering SETs with extensive teacher preparation were fully certified.

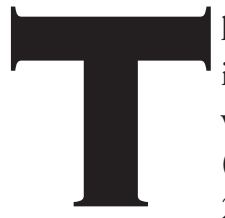

he shortage of qualified teachers in special education has been widely recognized in the field (McLeskey, Tyler, \& Flippin, 2004). The ERIC Clearinghouse on Disabilities and Gifted Education (2001) concluded that "The shortage of qualified special education teachers is critical" (p. 2). The most basic indicator of teacher qualification is certification (or licensure) status. While there are other important indicators, such as teaching experience and teacher professionalism (Carlson, Lee, Schroll, Klein, \& Willing, 2002), only teacher certification is required by both federal and state policy. Federal policy is embodied in the definition of a highly qualified teacher (HQT) contained in the No Child Left Behind Act of 2001 (NCLB, 2002). It requires that all teachers hold full state certification, not part certification (i.e., having had certification waived on an emergency, temporary, or provisional basis; NCLB). In addition, all states have established detailed requirements for 
the certification of teachers, and expect all teachers to be fully certified (National Association of State Directors of Teacher Education and Certification, NASDTEC, 2003). In view of the full certification requirement in public policy, it is important to understand the extent to which teachers earn this qualification.

To qualify for full certification, teachers need to meet high standards of preparation specified by each state (NASDTEC, 2003). The Department of Education's Office of Special Education Programs (OSEP) has reported the numbers of special education teachers (SETs) who are fully certified and are not fully certified in a series of Annual Reports to Congress for over 20 years (most recently OSEP, 2004). In fact, certification is the only indicator of teacher qualification reported by OSEP.

Certification is not only embedded in public policy; it impacts the practice of teaching, as demonstrated by research on first-time teachers. Based on classroom observations by one trained observer who was unaware of the certification status of teacher participants, fully certified SETs were substantially more effective than partly certified SETs in planning and delivering instruction, and in establishing a positive classroom environment (Nougaret, Scruggs, \& Mastropieri, 2005). In other research based on a large national sample, fully certified teachers were much more likely than partly certified teachers to report being better prepared to teach subject matter and better prepared in pedagogical skills (Boe, Shin, \& Cook, 2005).

Furthermore, fully certified teachers may produce higher levels of student academic achievement than partly certified teachers. Two reviews (Darling-Hammond, 2001; Wayne \& Youngs, 2003) have cited evidence demonstrating such an association, while another (Walsh, 2001) did not find such an association. The Secretary of Education concluded that scientifically rigorous evidence is lacking about the value of teacher certification for enhancing student learning, and recognized the need for continued research on teacher quality (U.S. Department of Education, 2003).

Shortage of fully certified teachers is defined by the extent to which teaching positions are not filled by such teachers. Shortage is almost entirely accounted for by employed teachers who have not earned full certification (i.e., positions are filled by teachers who are only partly certified), and to a minor extent by positions that are not filled (i.e., left vacant). Both partly certified SETs and vacant positions are included in counts of "not fully certified" by OSEP in its Annual Reports to Congress. According to the National Center for Education Statistics (NCES), only $0.2 \%$ of teaching positions in public schools nationwide were unfilled in 1993-1994, the most recent NCES data (Henke et al., 1997). In special education, however, national data for the same year (1993-1994) show that $1.1 \%$ of teaching positions were unfilled (OSEP, 1998, Section III).

The chronic shortage of fully certified SETs in the $9 \%-11 \%$ range has been well documented in three national datasets. OSEP reported that $9 \%-10 \%$ of all positions for SETs were not filled by fully certified teachers during the school years from 1987-1988 through 1995-1996 (OSEP, 1998, Section III). Based on three sample surveys conducted by NCES during 1987-1988 through 1993-1994, Boe, Bobbitt, Cook, and Barkanic (1998) reported that $10 \%-11 \%$ of all SETs were partly certified. Based on data from the Study on Personnel Needs in Special Education (SPeNSE) sample survey conducted in 1999-2000 by Westat (Carlson et al., 2002), we computed a shortage of fully certified SETs of $10.6 \%$ (partly certified teachers and vacant positions combined).

The national shortage of SETs is well documented. Annual surveys by the American Association for Employment in Education (e.g., 1999) have found most specializations of special education to have considerable shortage. Lauritzen (1999) reported a critical shortage of SETs in Wisconsin, and the Southern Regional Education Board (SREB, 2001) noted that "A top concern for Tennessee, as for other SREB states, is the need for special education teachers" (pg. 10). At the local level, exceptionally high demand for SETs was seen in $98 \%$ of urban school districts (Recruiting New Teachers, 2000).

Since there is little doubt about a serious and chronic shortage of fully certified SETs, it is important to examine how shortage varies by source of teacher supply, such as recent graduates of teacher preparation programs and the reserve pool. The most detailed national-level study of 
this type was reported by Boe, Cook, Bobbitt, and Terhanian (1998), who found that entering SETs (i.e., those not already employed as teachers) exacerbated the shortage of fully certified SETs. This is because $31.8 \%$ of entering SETs were partly certified, in contrast to only $7.8 \%$ of continuing SETs.

How might sources of teacher supply improve, or exacerbate, the serious and chronic shortage? There is no national information on the certification status of those who enter teaching in special education from the reserve pool with different amounts of teacher preparation, or with teacher preparation in an area of general education. Fortunately, the most recent NCES Schools and Staffing Survey (SASS) for school year 1999-2000 has been expanded to include national data that now permits an analysis of these and other issues regarding the certification status of teachers of special education. This study updated and expanded the earlier study by Boe, Cook, et al. (1998) on teacher certification, which was based on data from 1990-1991. More specifically, this new research investigated, in national perspective, the certification status of continuing and entering public school SETs drawn from various sources of supply. This includes individuals hired from the reserve pool, and those who recently completed differing amounts of teacher preparation. This investigation was intended to identify the major sources of not fully certified SETs. Efforts by education policymakers and executives to address teacher shortages can benefit from better information about this pressing problem.

\section{ET HOD}

\section{Data Sources and TeaCHer Samples}

The main data source was teacher responses to the 1999-2000 Public School Teacher Questionnaire (PSTQ), a component of SASS. PSTQ data provide details about teacher supply (e.g., continuing vs. entering teachers), amount of teacher preparation (extensive, some, vs. none), teaching position (e.g., special vs. general education), and teacher qualification (e.g., certification status). In addition, trend data for teacher certification were obtained from similar versions of PSTQ from the 1987-1988, 1990-1991, and 1993-1994 SASS.

The certification status of teachers in special
education suffers by the hiring of too many
out-of-field teachers, less than a quarter of
whom earned full certification in special
education.

The 1999-2000 PSTQ provides nationally representative estimates of the numbers of public school teachers of various types. Specifically, PSTQ data were obtained from a large national probability sample of public school teachers $(N=$ 53,105 , including public charter school teachers) with a weighted questionnaire response rate of $83 \%$. This yielded a sample of $44,896 \mathrm{~K}-12$ teachers who completed the PSTQ. There are no missing data for completed PSTQs because NCES imputed values for item nonresponse. Tourkin et al. (2004) reports detailed information about the 1999-2000 SASS. In addition to SASS, we obtained longitudinal data on the percentage of fully certified teachers serving children ages 6 to 21 with disabilities from OSEP's Data Analysis System (DANS) for the 1987-1988 through 2001-2002 school years, contained in the Annual Reports to Congress (e.g., OSEP, 2004).

\section{TEACHER DEFINITIONS}

In keeping with SASS definitions, a "teacher" was any individual who reported being employed either full-time or part-time at a public school with a main assignment of teaching in Grades $\mathrm{K}-12$, including itinerant teachers and long-term substitutes. This definition excludes individuals who identify their main assignment as prekindergarten teacher, short-term substitute, student teacher, teacher aide, or a nonteaching specialist of any kind.

The PSTQ asked teachers to designate one of 64 main teaching assignment fields as their primary instructional area. We divided these 64 fields into two main areas: special education and general education. Special education included 15 main teaching assignment fields such as deaf and hard-of-hearing, developmentally delayed, and 
FIGURE I

Sources of Teaching Force, School Year 1999-2000

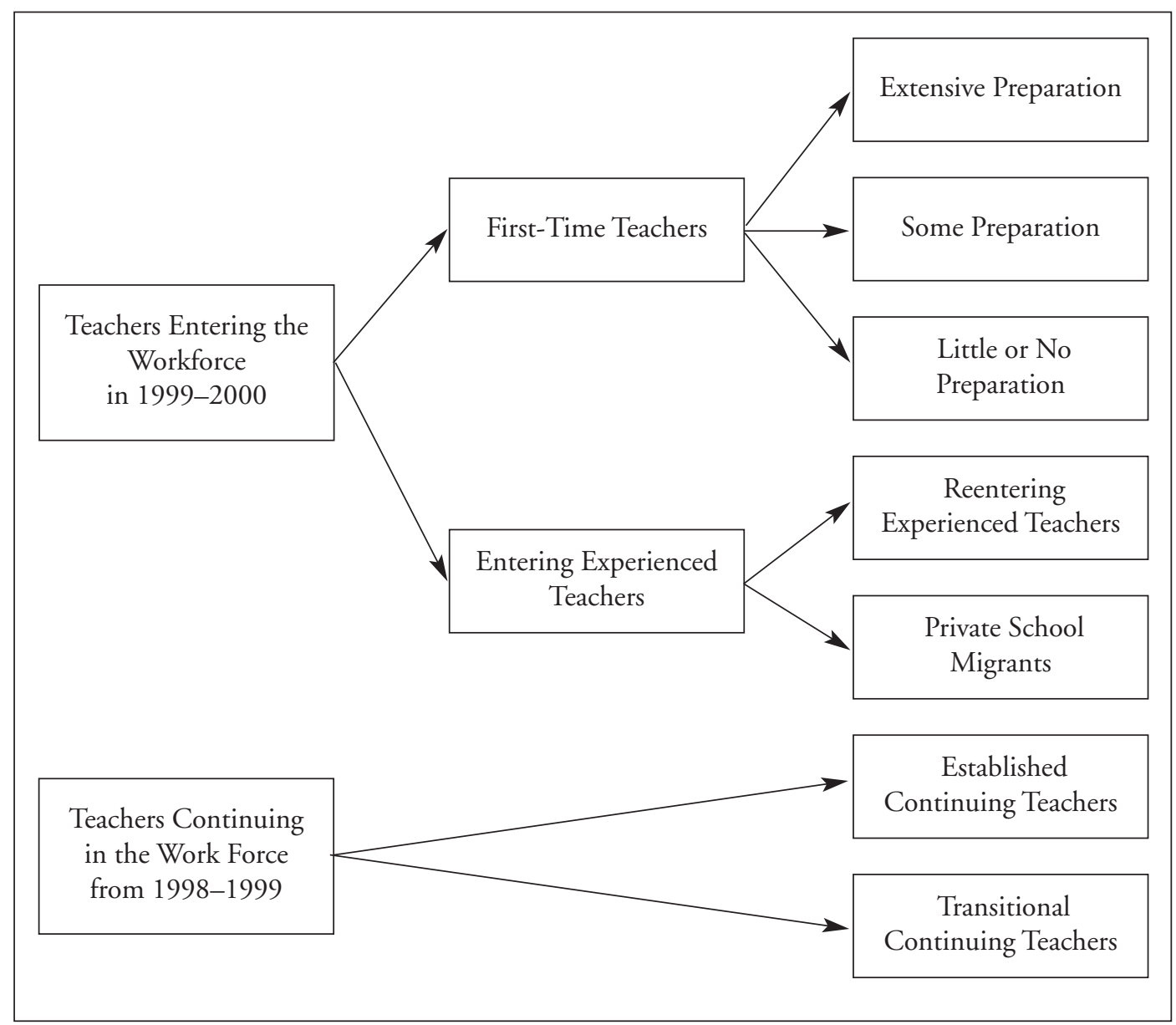

learning disabilities. All teachers who designated one of these 15 fields as their main teaching assignment were defined as SETs. Given that the PSTQ included a category for "other special education," all elementary and secondary teachers with a main assignment in any area of special education should have been able to identify themselves as such, regardless of the particular certification terminology used in their home state. General education teachers (GETs) were then defined as all public school teachers $(\mathrm{K}-12)$ other than SETs.

\section{DESIGN}

The research was designed to analyze, from a national perspective, the certification status of the
SET supply, in comparison with GETs, employed in public schools during school year 1999-2000. We focused on the sources of the supply of public school teachers who entered the teaching force in 1999-2000, and others who continued in public schools from the prior year. The two main supply sources of teachers are (a) entering teachers (individuals who were not teaching in public schools during the 1998-1999 school year, and who commenced teaching in a public school during the subsequent school year) and (b) continuing teachers (individuals who were teaching in a public school during 1998-1999, and who continued teaching in a public school during the next school year; see Figure 1). 


\section{ENTERING TEACHER SUPPLY}

The supply group of entering teachers was subdivided into those who were (a) first-time teachers, with no prior teaching experience in either public or private schools (other than possibly as teacher aides, student teachers, or short-term substitute teachers) and varying amounts of teacher preparation (or no preparation), and (b) those with prior teaching experience.

First-Time Teachers. PSTQ collects quantitative information on practice teaching experience: 10 weeks or more, 5 to 9 weeks, 1 to 4 weeks, or no practice teaching. There are four common components of teacher preparation: (a) coursework in selecting and adapting instructional materials, (b) coursework in educational psychology, (c) observation time of other classroom teaching, and (d) feedback received on their teaching. Extensive practice teaching and these common components are ordinarily required by states for teacher certification. According to NASDTEC's data from 50 states and the District of Columbia (2003, Table B-8), 8 weeks of practice teaching is the minimum required for an initial teaching certificate; this coincides with information from the American Association of Colleges of Teacher Preparation (D. Imig, Director, personal communication, April 7, 2003). In addition, almost all states require coursework in the psychological foundations of teaching, teaching methods, and field experience prior to student teaching (NASDTEC, Tables B-5, B-6, and B-7).

Given this background and using specific configurations of the length of the practice teaching experience and the completion of the four common components of teacher preparation, we defined three levels of teacher preparation.

1. Extensive teacher preparation was defined as completing either (a) 10 or more weeks of practice teaching along with all four of the common components of traditional teacher preparation listed previously, (b) 10 or more weeks of practice teaching and some of the four common components of traditional teacher preparation, or (c) 5 to 9 weeks of practice teaching along with all four common components of teacher preparation. The percentages of all first-time teachers so classified were $79 \%, 11 \%$, and $10 \%$, respectively.
2. Some teacher preparation was defined as completing either (a) 5 to 9 weeks of practice teaching and some of the four common components of traditional teacher preparation listed above, (b) 1 to 4 weeks of practice teaching and all or some of the four common components of teacher preparation, or (c) no practice teaching but all four common components of teacher preparation. The percentages of all first-time teachers so classified were $23 \%, 36 \%$, and $41 \%$, respectively.

3. All other teachers without practice teaching were defined as having little or no teacher preparation. Of such first-time teachers, 32\% did not complete any of the four common components of teacher preparation listed above, while $68 \%$ completed some of these four components.

Experienced Teachers. Entering experienced teachers had not been employed as teachers in public schools during the preceding 1998-1999 school year, and comprised two subtypes: (a) private school migrant teachers, who transferred from private to public schools; and (b) reentering experienced teachers, who had left teaching employment in either public or private schools. Such former teachers represent one component of the reserve pool, a major source of supply of entering teachers. (The other component of the reserve pool, described later, is delayed entrants, college graduates who have participated in teacher preparation programs, but who delayed entering teaching employment by more than 1 year following their graduation.)

\section{CONTINUing TEACHER Supply}

The other main supply source was the group of continuing teachers, individuals who were teaching in a public school during 1998-1999, and who continued teaching in a public school during the next school year. A continuing teacher may have continued in the same school and teaching assignment, or may have changed school and/or teaching assignment from one school year to the next school year. Continuing teachers were subdivided into two types representing stability in teaching assignments. 
Established Continuing Teachers. Established teachers were defined as continuing teachers who had remained in 1 of 64 specific teaching assignment fields recognized by SASS and who had taught in the same school during the 1998-1999 and 1999-2000 school years.

Transitional Continuing Teachers. Transitional teachers were defined as all continuing teachers who were not classified as established teachers, and included (a) continuing teachers who had changed teaching assignment and/or school since 1997-1998, and (b) those who had entered public school teaching during 1998-1999 (i.e., too recently to have had sufficient years of service to qualify as established teachers).

\section{Other TEACHER SUPply VARIAbLES}

Our research design also included other teacher supply and qualification variables, that is, time of entry, field of degree major, and certification status.

Time of Entry. First-time teachers with teacher preparation were classified according to the number of years between college graduation and entry into the ranks of employed teachers: (a) recent graduates were entering first-time teachers with teacher preparation who had earned a college or university degree at the bachelor's or graduate levels during calendar year 1999, and (b) delayed entrants were entering first-time teachers with teacher preparation who had not earned a college or university degree at the bachelor's or graduate levels during calendar year 1999, but who had earned a degree during some prior year. Delayed entrants, along with reentering experienced teachers, comprise the reserve pool.

Field of Degree Major. Teachers were classified according to the academic or professional field(s) in which they had majored; teachers who had completed at least one major in a field of teacher preparation at either the bachelor's or master's degree levels were classified as having a major in teacher preparation. We further subdivided this group between those whose teacher preparation major was in special education and those whose teacher preparation major was in general education. All teachers who were not classified as having majored in a field of teacher preparation were classified as having other degree majors.
Certification Status. Three methods were used to define the certification status of teachers. First, teachers were classified as either fully or partly certified in their main teaching assignment. Fully certified teachers qualified for either an advanced professional certificate, a regular or standard state certificate, or a probationary certificate (i.e., all requirements satisfied except for completion of a probationary period) specifically in the field of their main teaching assignment (i.e., in 1 of 64 specific teaching assignment fields recognized by SASS). All teachers who were not so fully certified were classified as partly certified teachers in their main teaching assignment; most of these teachers would have qualified for temporary, provisional, or emergency certification, though some may have held no certificate at all in their main teaching assignment.

Second, teachers were classified as either fully or partly certified in the cognate area of their main teaching assignment. To accomplish this, the research team grouped the 64 specific main teaching assignments into eight cognate areas: (a) general elementary education (including kindergarten); (b) mathematics and science (including all science fields and computer science); (c) language (including reading, English/language arts, TESOL/ESL, foreign languages, etc.); (d) social studies/science (including history, philosophy, religion); (e) arts and physical education (including art, music, dance, drama, and health education); (f) business/vocational education (including home economics, health occupations, etc.); (g) other general education (including bilingual, basic skills and remedial, gifted, etc.); and (h) special education (including 15 subspecializations).

A fully certified teacher in a cognate area qualified for either an advanced professional certificate, a regular or standard state certificate, or a probationary certificate (i.e., all requirements satisfied except for completion of a probationary period) in any main teaching assignment within that cognate area. All teachers who were not fully certified in any of the main teaching assignments in their cognate area were classified as partly certified in their cognate area.

Third, teachers were classified as either fully or partly certified in any teaching assignment. All teachers who were fully certified in one (or more) teaching field(s), regardless of their teaching 
assignment, were defined simply as fully certified. All teachers who were not fully certified in any teaching field were classified as partly certified.

\section{TEACHER SHORTAGE}

Because all teachers should be fully certified in their main teaching assignment, we defined teacher shortage primarily by the number of teachers who were not fully certified in their main teaching assignment. Teacher shortage was also defined (a) as the number of teachers who were not fully certified in any teaching assignment within their cognate area, and (b) as the number of teachers who were not fully certified in any teaching assignment or cognate area. Technically, teacher shortage should represent the sum of the number of partly certified employed teachers plus the number of open, but unfilled, teaching positions. However, as demonstrated by the 1990-1991 and 1993-1994 SASS, the percentage of unfilled teaching positions in all teaching fields combined has been about $0.2 \%$ (Henke et al., 1997) and such data are unavailable for specific teaching fields. For teacher shortage percentages based on SASS data, therefore, the small number of unfilled positions is not included in the quantification of teacher shortage. For teacher shortage percentages based on DANS data from OSEP, the larger number of vacant positions is included in the quantification of teacher shortage.

\section{ANALYSIS PROCEDURES}

We used special procedures developed by NCES for complex sample survey data (Tourkin et al., 2004) to compute national estimates of the numbers of teachers of each type included in the design described previously (along with associated percentages and standard errors). Because SASS data are subject to design effects due to stratification and clustering of the sample, we computed standard errors for the national estimates and tests of statistical significance via balanced repeated replications using WesVar complex sample software (Westat, 2002). We performed chi-square tests of the statistical significance of differences among teacher supply and certification variables as a function of teaching field (special vs. general education) on the nationally estimated numbers of teachers.

\section{RES ULTS}

The results of this research are organized as responses to six main questions about the national shortage of fully certified teachers in public schools. Separate parallel analyses for special and general education permit comparisons between these two broad teaching fields.

\section{To What EXTENT IS the Shortage of FulLy CERTIFIED TEACHERS CHRONIC AND INCREASING?}

Figure 2 illustrates the long-term trend in the shortage of fully certified SETs. This figure is based on population data collected annually from state administrative records by OSEP, as provided in its Annual Reports to Congress (e.g., OSEP, 2004), and demonstrates the chronic shortage of SETs since 1987-1988 (i.e., a 15-year period). These data also demonstrate the increasing shortage of fully certified SETs during the most recent 8 years (from $7.4 \%$ in $1993-1994$ to $12.2 \%$ in 2001-2002). Not only did the shortage percentage of SETs increase by over $50 \%$ during this most recent period, but the number of additional fully certified SETs needed (i.e., to replace partly certified SETs) almost doubled from 25,000 to 49,000 .

This trend in the national shortage of fully certified SETs is replicated in SASS sample-survey data from 1987-1988 through 1999-2000 (see Figure 3). Figures 2 and 3 both show an increasing shortage of fully certified SETs culminating at about the $12 \%$ level by the end of the 20th century. Given the consistency of findings from two different sources of data, there is compelling evidence that the shortage of fully certified SETs is serious and chronic, and has been increasing steadily during recent years.

\section{Is the Shortage Problem Related to TYPE OF CONTINUING TEACHERS?}

Table 1 presents shortage results in terms of the national percentages of partly certified teachers of two types: (a) established teachers (i.e., who had remained in the same main teaching assignment and in the same school for at least 2 consecutive years), and (b) transitional teachers (i.e., who had not served in the same assignment and school for 
F I G U R E 2

Percentage Shortage of Fully Certified Special Education Teachers Nationally by School Year

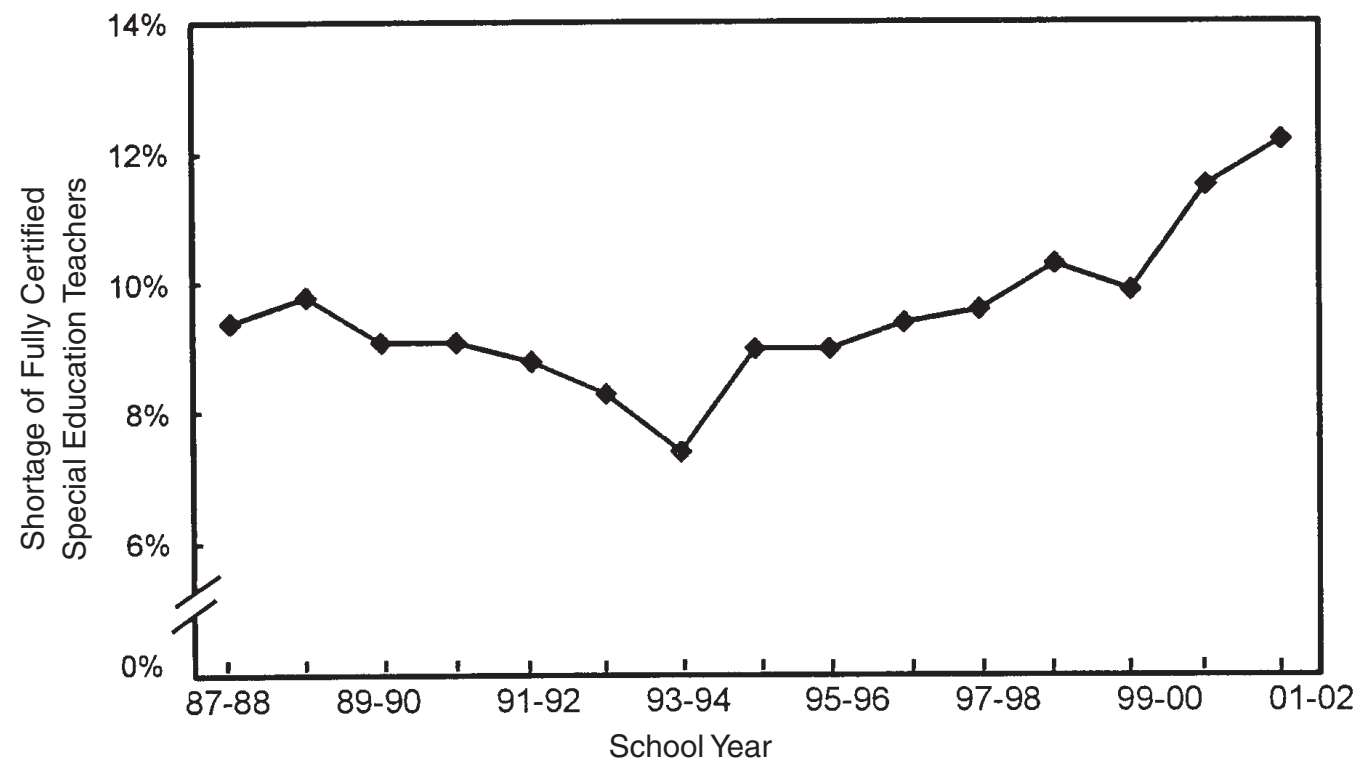

Note: Shortage is defined as the percentage of total special education teaching positions in public schools that are not filled by teachers who are fully certified in their main teaching assignments. This includes special education teachers who are less than fully certified plus vacant teaching positions.

Data Sources: OSEP's series of Annual Reports to Congress.

2 consecutive years). As seen, a considerably higher percentage of transitional teachers were only partly certified than were established teachers. This problem was greater in special education where $23.2 \%$ of transitional SETs were partly certified in comparison with $16.6 \%$ of transitional GETs [a statistically significant difference; $\chi^{2}(1, N$ $=5,333)=18.67, p<.001]$.

A striking finding seen in Table 1 is that relatively low and equivalent percentages of established SETs and GETs were only partly certified ( $7.4 \%$ vs. $7.6 \%$, respectively). This result indicates that, once established in their teaching positions, SETs are as qualified as GETs (in terms of full certification). Accordingly, the most serious shortage of fully certified SETs does not reside principally in the main body of continuing teachers in special education, $77.7 \%$ of whom were classified as established teachers.

By contrast with established SETs, a more serious problem lies in the relatively high numbers of transitional SETs who were only partly certified $(23.2 \%)$. The most serious problem lies in the high percentage of entering SETs who are only partly certified (44.4\%).

Nonetheless, the shortage of fully certified SETs is a major problem in both categories of continuing teachers. A shortage of $7.4 \%$ of fully certified established SETs (though equivalent to that of established GETs) is not trivial. In terms of numbers of teachers, 19,000 established SETs and 11,000 transitional SETs (out of a total of 304,000 continuing SETs) were not fully certified during the 1999-2000 school year.

\section{How Do ENTERING TeACHERS AFFECT THE SHORTAGE OF FULLY CERTIFIED TEACHERS?}

It might be expected that the chronic shortage of fully certified SETs would lessen year by year as more qualified teachers were hired into the teaching force. However, as seen in Table 1, the percentage of partly certified entering SETs (44.4\%) in 1999-2000 was much higher than that of partly certified continuing SETs [9.9\%, a statisti- 
F I G U R E 3

Percentage of Partly Certified Teachers Nationally by School Year

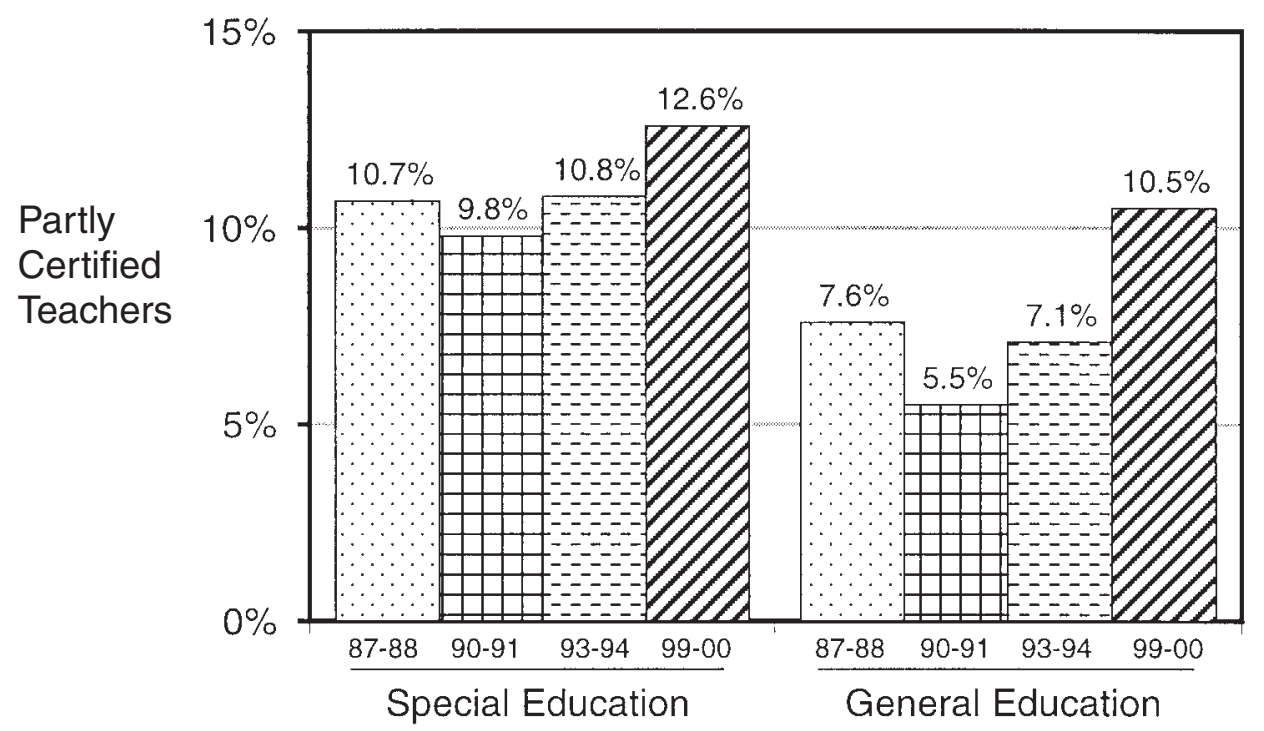

Data sources: The 1987-1988, 1990-1991, 1993-1994, and 1999-2000 Schools and Staffing Surveys, National Center for Education Statistics, USDE.

cally significant difference; $\chi^{2}(1, N=4,119)=$ $384.47, p<.001]$. Thus, entering SETs increased the overall shortage percentage that stood at $12.6 \%$ of all SETs in $1999-2000$.

The percentage of partly certified entering GETs (31.2\%) also was much higher than the comparable percentage of continuing GETs $(8.7 \%)$. The differences between the shortages of fully certified entering SETs (44.4\%) and GETs $(31.2 \%)$ was a matter of degree; that is, the shortage of fully certified entering teachers was a problem in both fields. Overall, the shortage of fully certified teachers in special education was not only large in absolute terms (12.6\% of all SETs), but somewhat larger than in general education [10.5\% of all GETs, a statistically significant difference; $\left.\chi^{2}(1, N=44,896)=20.89, p<.001\right]$.

So, the percentage of partly certified entering SETs was high, as shown in Table 1 (44.4\% in 1999-2000); this trend has been increasing during the past decade $(31.3 \%$ in 1990-1991; $34.5 \%$ in 1993-1994; Boe, Bobbitt, Cook, Barkanic, \& Maislin, 1998a). Given these findings, it is not surprising that there has been a corresponding trend of increasing overall shortage of fully certified teachers in special education, as il- lustrated in Figures 2 and 3. Positive factors, such as year-to-year improvement in certification credentials of continuing SETs through professional development, have been insufficient to overcome the negative effects of the extraordinarily high percentage of partly certified entering SETs. This highlights the importance of improving the qualifications of the pool of applicants from which entering teachers are hired.

\section{Is the Shortage Problem Related TO THE SOURCES OF SUPPLY OF ENTERING TEACHERS?}

We subdivided the two main supply sources for entering teachers (i.e., first-time and experienced) into seven particular sources of entering teachers. It is apparent from the results (see Table 2) that the percentages of partly certified SETs varied greatly according to supply source (from $26.8 \%$ for reentering experienced SETs, to $98.6 \%$ for first-time SETs with only some preparation). It also is apparent that the percentages of partly certified SETs were consistently higher than for GETs.

Table 2, further, illustrates the substantial difference between the partly certified percentages 
National Estimates of Percentage of Teachers Partly Certified in Their Main Teaching Assignment by Supply Source, 1999-2000 School Year

\begin{tabular}{|c|c|c|c|c|c|c|c|c|}
\hline \multirow[b]{3}{*}{ Supply Source } & \multicolumn{4}{|c|}{ Special Education } & \multicolumn{4}{|c|}{ General Education } \\
\hline & \multicolumn{2}{|c|}{ Partly Certified $^{a}$} & \multicolumn{2}{|c|}{ Total Teachers } & \multicolumn{2}{|c|}{ Partly Certified $^{b}$} & \multicolumn{2}{|c|}{ Total Teachers } \\
\hline & $\%$ & SE $\%$ & Number & Col\% & $\%$ & SE $\%$ & Number & Col \% \\
\hline \multicolumn{9}{|l|}{ Continuing Teachers } \\
\hline Established Teachers & 7.4 & 0.7 & 256,489 & 77.7 & 7.6 & 0.3 & $2,154,543$ & 80.8 \\
\hline Transitional Teachers & 23.2 & 2.8 & 47,890 & 14.5 & 16.6 & 0.8 & 303,651 & 11.4 \\
\hline Subtotal: Continuing & 9.9 & 0.7 & 304,379 & 92.2 & 8.7 & 0.2 & $2,458,195$ & 92.1 \\
\hline \multicolumn{9}{|l|}{ Entering Teachers } \\
\hline First-Time Teachers & 60.2 & 5.6 & 13,292 & 4.0 & 38.1 & 1.8 & 113,907 & 4.3 \\
\hline Experienced Teachers & 27.7 & 3.6 & 12,626 & 3.8 & 23.1 & 1.5 & 96,002 & 3.6 \\
\hline Subtotal: Entering & 44.4 & 3.9 & 25,917 & 7.9 & 31.2 & 1.3 & 209,909 & 7.9 \\
\hline Total Teaching Force ${ }^{\mathrm{c}}$ & 12.6 & 0.8 & 330,297 & 100.1 & 10.5 & 0.2 & $2,668,103$ & 100.0 \\
\hline
\end{tabular}

Note. Data from the 1999-2000 Schools and Staffing Surveys, National Center for Education Statistics, USDE.

Partly Certified $\%=$ percentage of partly certified teachers out of the total number of nationally estimated teachers for each source of supply. SE $\%=$ standard error of the partly certified percentages. Col. $\%=$ column percentages of the nationally estimated number of teachers.

${ }^{a}$ For special education teachers, the supply source by full- vs. part-certification $\chi^{2}(3, N=4,919)=613.4, p<.001$. ${ }^{b}$ For general education teachers, the supply source by full- vs. part-certification $\chi^{2}(3, N=39,977)=2106.8, p<.001$. ${ }^{\mathrm{c}}$ The sample size $(N)$ for total teachers was 4,919 for special education and 39,997 for general education.

for SET and GET recent graduates $[41.0 \%$ vs. $27.5 \%$, respectively, a statistically significant difference; $\left.\chi^{2}(1, N=938)=8.52, p<.01\right]$. Likewise, the difference between the partly certified percentages for SETs and GETs entering from the reserve pool $(42.7 \%$ vs. $28.1 \%$, respectively) was statistically significant $\left[\chi^{2}(1, N=2,649)=25.64\right.$, $p<.001]$. Overall, a substantially higher percentage of entering SETs $(44.4 \%)$ were partly certified than entering GETs $\left[31.2 \% ; \chi^{2}(1, N=4,140)=\right.$ $31.90, p<.001]$.

For special education, about $98 \%$ of both first-time teachers with only some preparation and those with no preparation were partly certified in their main teaching assignments. These two groups represent over $13 \%$ of all entering SETs. The partly certified percentages for entering GETs drawn from these sources were somewhat lower (but still high, ranging from $70.4 \%-$ $91.4 \%)$. Given that these particular sources of entering teacher supply produce so few fully certified teachers, one might ask why these sources are being used. We hypothesize that there is insuffi- cient supply of fully certified teachers from other sources who apply for the positions that are filled with partly certified teachers.

The best sources of fully certified SETs and GETs for public schools are recent graduates who have completed extensive teacher preparation, reentering experienced teachers, and private school migrants (though $22 \%=36 \%$ of entering teachers from these sources are only partly certified). However, first-time SETs with extensive teacher preparation who delayed entry to the teaching force yielded considerably higher percentages of partly certified teachers $(64.9 \%$, vs. $35.9 \%$ for recently graduated SETs).

Consequently, the overall qualifications of the teaching profession would be improved by hiring recent graduates with extensive preparation, and experienced teachers, over other sources of entering teacher supply. Even so, the hiring of recent graduates with extensive teacher preparation would actually increase the quality demand for fully certified replacement teachers rather than reduce it, as might be hoped. Therefore, the solu- 
TABLE 2

National Estimates of Percentage of Entering Teachers Partly Certified in Their Main Teaching Assignment by Supply Source, 1999-2000 School Year

\begin{tabular}{|c|c|c|c|c|c|c|c|c|}
\hline \multirow[b]{3}{*}{ Supply Source: Entering Teachers } & \multicolumn{4}{|c|}{ Special Education } & \multicolumn{4}{|c|}{ General Education } \\
\hline & \multicolumn{2}{|c|}{ Partly Certified ${ }^{a}$} & \multicolumn{2}{|c|}{ Total Teachers } & \multicolumn{2}{|c|}{ Partly Certified $^{b}$} & \multicolumn{2}{|c|}{ Total Teachers } \\
\hline & $\%$ & SE $\%$ & Number & Col\% & $\%$ & SE $\%$ & Number & Col \% \\
\hline \multicolumn{9}{|l|}{ First-Time Teachers: Recent Graduates } \\
\hline With Extensive Teacher Preparation & 35.9 & 7.7 & 6,129 & 23.7 & 24.6 & 2.1 & 48,035 & 22.9 \\
\hline With Some Teacher Preparation & $98.6^{\mathrm{d}}$ & 2.7 & 539 & 2.1 & 70.4 & 8.1 & 3,237 & 1.5 \\
\hline Subtotal: Recent Graduates ${ }^{\mathrm{c}}$ & 41.0 & 7.8 & 6,668 & 25.8 & 27.5 & 2.2 & 51,272 & 24.4 \\
\hline
\end{tabular}

Reserve Pool

First-Time Teachers: Delayed Entry

With Extensive Teacher Preparation

$2.7 \quad 45,851$

21.8

With Some Teacher Preparation

$98.2^{\mathrm{d}} \quad 2.7 \quad 1,594$

$6.2 \quad 86.6$

$3.9 \quad 6,591$

3.1

Reentering Experienced Teachers

$26.8 \quad 4.0 \quad 10,801$

$41.7 \quad 21.8$

$1.5 \quad 82,861$

39.5

Subtotal: Reserve Pool ${ }^{\mathrm{e}}$

$42.7 \quad 4.7 \quad 16,101$

$62.2 \quad 28.1$

$1.535,301$

64.4

Other Entering Teachers

First-Time Teachers Without Teacher

Preparation

Private School Migrants

$97.8^{\mathrm{d}} \quad 1.5 \quad 1,324$

5.1

91.4

$2.210,194$

4.9

Subtotal: Other Entering Teachers

$32.9^{\mathrm{d}} \quad 11.1 \quad 1,824$

$7.0 \quad 31.3$

$5.4 \quad 13,141$

6.3

$60.2 \quad 10.9 \quad 3,149$

$12.1 \quad 57.6$

$3.9 \quad 23,335$

11.2

Total Entering Teachers ${ }^{\mathrm{f}}$

44.

$3.9 \quad 25,918 \quad 100.1$

31.2

$\begin{array}{lll}1.3 & 209,909 & 100.0\end{array}$

Note. Data from the 1999-2000 Schools and Staffing Surveys, National Center for Education Statistics, USDE. Partly Certified $\%=$ percentage of partly certified teachers out of the total number of nationally estimated teachers for each source of supply. SE $\%=$ standard error of the partly certified percentages. Col. $\%=$ column percentages of the nationally estimated number of teachers.

${ }^{a}$ For special education teachers, the supply source by full- vs. part-certification $\chi^{2}(6, N=4,919)=111.1, p<.001$. ${ }^{b}$ For general education teachers, the supply source by full- vs. part-certification $\chi^{2}(6, N=39,977)=586.0, p<.001$. ${ }^{\text {FFor }}$ recent graduates, full- vs. part-certification by teaching field $\chi^{2}(1, N=938)=8.5, p<.01$. dSample size $(n)$ is less than

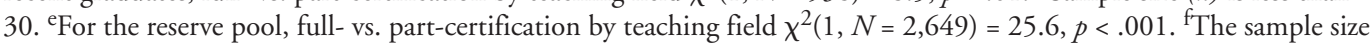
$(N)$ for total entering teachers was 457 for special education and 3,683 for general education.

tion to the shortage of fully certified teachers is not found simply in recruiting sufficient numbers of such teachers available from entering supply pools.

\section{Is the Shortage Problem Related to THE SoURCES of SUPpLY of FIRST-TIME TEACHERS?}

In order to analyze in more detail the reasons why a much smaller percentage of entering first-time teachers in special education were fully certified than in general education, we investigated the particular fields of study in which first-time teachers earned degrees. As seen in Table 3, the predominant differences between first-time SETs and GETs are seen in those who completed extensive teacher preparation: $74.0 \%$ of first-time SETs and $82.4 \%$ of first-time GETs. For these teachers, the partly certified percentage of SETs (46.9\%) was much greater than that of GETs $(27.7 \%)$, $\chi^{2}(1, N=1,681)=25.36, p<.001$. However, there was no appreciable difference between partly certified SETs and GETs when their degree major was in the same field as their teaching assignment (28.5\% vs. $24.9 \%$, respectively). 
The main source of partly certified first-time SETs with extensive teacher preparation was the $17.6 \%$ of SETs who had degree majors in general education and the $9.9 \%$ who had majors in other fields (i.e., such as mathematics or English). By contrast, only $0.5 \%$ of GETs with extensive teacher preparation had a degree major in special education. In short, the certification status of teachers in special education suffers by the hiring of too many out-of-field teachers, less than a quarter of whom earned full certification in special education. Additionally, $26.1 \%$ of first-time SETs received only some teacher preparation or no teacher preparation; of this group, practically none were fully certified.

\section{To What EXtent Is the Shortage \\ PROBLEM DUE TO MisassignMENT OF FulLY CERTIFIED TEACHERS?}

It has been thought that improving the match between teacher certification and assignment (i.e., reducing out-of-field teaching) could potentially reduce the shortage of fully certified teachers (Ingersoll, 2002). To examine the degree to which this might be true, we analyzed the extent to which SETs and GETs who were only partly certified in a particular main teaching assignment were fully certified in a different main teaching assignment. The results are shown in Table 4 for the entire teaching forces in special and general education, and in Table 5 for first-time teachers in these fields.

Table 4 shows that $12.6 \%$ of all SETs were partly certified in one of 15 specific main teaching fields to which they were assigned within special education (e.g., developmentally delayed, learning disabilities, visually impaired, etc.). Of the teachers without such full certification, only $1.0 \%$ were fully certified in a different specific main teaching assignment within special education (i.e., $11.6 \%$ of SETs were not fully certified in any of the 15 main teaching assignments within special education). Thus, only a small component of the shortage of fully certified SETs can be attributed to misassignment of SETs within special education.

Of the $11.6 \%$ of all SETs who were not fully certified in 1 of 15 specializations within special education, it might be expected that many were fully certified in a particular teaching assignment within general education. As seen in Table 4, $9.0 \%$ of all SETs did not have full certification in any teaching assignment, general or special education. This can be viewed as the remarkably large core of SETs who lack the basic credentials to be employed as a teacher.

The best sources of fully certified SETs and
GETs for public schools are recent graduates
who have completed extensive teacher
preparation, reentering experienced
teachers, and private school migrants.

In addition, the difference between the $11.6 \%$ of SETs who were not fully certified in special education and the $9.0 \%$ who were not fully certified in any teaching assignment (i.e., $2.6 \%)$ is a measure of the percentage of all SETs who were fully certified in a teaching assignment only in general education. These represent potential future crossover teachers from special to general education assignments, many of whom switch annually (Boe, Bobbitt, Cook, Barkanic, \& Maislin, 1998b).

As shown in Table 4, the pattern of partial certification by the three categories of teaching assignments for GETs was much the same as for SETs (though the partly certified percentages for GETs were slightly lower). Accordingly, $10.5 \%$ of GETs were partly certified in their main teaching assignment, while $9.9 \%$ were partly certified in some other teaching assignment within their cognate area. The difference $(0.6 \%)$ represents teachers who were fully certified in a teaching assignment in their cognate area, but not the one that was their main assignment. Similarly, 8.3\% of GETs were not fully certified in any main teaching assignment. Thus, for both special and general education, there has not been massive misassignment of fully certified teachers to positions for which they did not hold full certification. Instead, it appears that there has simply been insufficient supply to satisfy the demand for fully certified teachers. 
TABLE 3

National Estimates of Percentage of First-Time Teachers Partly Certified in Their Main Teaching Assignment by Teacher Preparation and Degree Major, 1999-2000 School Year

\begin{tabular}{|c|c|c|c|c|c|c|c|c|}
\hline \multirow[b]{3}{*}{ Supply Source: First-Time Teachers } & \multicolumn{4}{|c|}{ Special Education } & \multicolumn{4}{|c|}{ General Education } \\
\hline & \multicolumn{2}{|c|}{ Partly Certified $^{a}$} & \multicolumn{2}{|c|}{ Total Teachers } & \multicolumn{2}{|c|}{ Partly Certified $^{b}$} & \multicolumn{2}{|c|}{ Total Teachers } \\
\hline & $\%$ & SE \% & Number & Col \% & $\%$ & SE $\%$ & Number & $\mathrm{Col} \%$ \\
\hline \multicolumn{9}{|l|}{ With Extensive Teacher Preparation } \\
\hline Major in Same Teaching Field & 28.5 & 8.4 & 6,175 & 46.5 & 24.9 & 2.0 & 62,274 & 54.7 \\
\hline Major in Other Teaching Field & 73.5 & 10.3 & 2,341 & 17.6 & $27.2^{\mathrm{c}}$ & 11.4 & $-^{c}$ & 0.5 \\
\hline $\begin{array}{l}\text { Other Major } \\
\text { Subtotal: With Extensive }\end{array}$ & $85.4^{\mathrm{c}}$ & 11.0 & $-^{c}$ & 9.9 & 33.4 & 3.3 & 31,002 & 27.2 \\
\hline Teacher Preparation ${ }^{\mathrm{d}}$ & 46.9 & 6.7 & 9,835 & 74.0 & 27.7 & 1.8 & 93,886 & 82.4 \\
\hline With Some Teacher Preparation & $98.3^{\mathrm{c}}$ & 1.9 & $-^{c}$ & 16.1 & 81.3 & 4.3 & 9,827 & 8.6 \\
\hline Without Teacher Preparation & $97.8^{\mathrm{c}}$ & 1.5 & $-^{c}$ & 10.0 & 91.4 & 2.2 & 10,193 & 9.0 \\
\hline Total First-Time Teachers ${ }^{\mathrm{e}}$ & 60.2 & 5.6 & 13,292 & 100.1 & 38.1 & 1.8 & 113,907 & 100.0 \\
\hline \multicolumn{9}{|c|}{ 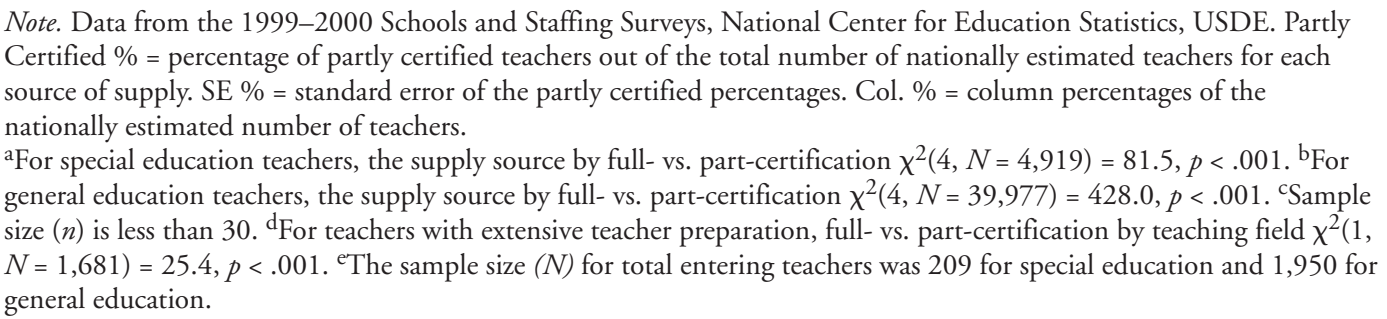 } \\
\hline
\end{tabular}

Table 5 illustrates the high levels of partial certification of first-time SETs and GETs (as first seen in Table 1), and the contrast between the percentages of partly certified first-time teachers in these fields. For both fields, however, there is not a large or statistically significant difference in the percentage of partly certified first-time teachers, whether in their main teaching assignment or in any teaching assignment within their cognate area. Table 5 shows that for first-time teachers, there has not been massive misassignment of fully certified teachers to positions for which they did not hold full certification. Instead, there appears be a shortage in the supply of fully certified teachers.

\section{DISCUSSION}

\section{LIMITATIONS}

This research provides the first national information specifically on certification status of first- time SETs and GETs as a function of three amounts of teacher preparation (extensive, some, or none). It also provides the most recent national information on trends from 1987-1988 through 2001-2002 regarding certification of SETs and GETs. Because these results are based on large national-probability samples of teachers, they should not be interpreted as directly applicable to the state or local levels unless supported by other data at the relevant level.

\section{Implications for POLICY, PRACTICE, AND FURTHER RESEARCH}

Our findings show that the shortage of fully certified SETs has been chronic, increasing, and serious. Following a gradual decline in the percentage shortage of SETs from 1987-1988 to 19931994 , the shortage gradually increased from $7.4 \%$ in $1993-1994$ to $12.2 \%$ in $2001-2002$, and ranged from $2 \%$ to $4 \%$ greater than for GETs. As the teaching force in special education grew 
TA B L E 4

Percentage of Total Special and General Education Teachers Who Were Partly Certified: National Estimates by Category of Teaching Assignment, 1999-2000 School Year

\begin{tabular}{llrc}
\hline \multirow{2}{*}{$\begin{array}{l}\text { Certification by } \\
\text { Teaching Assignment }\end{array}$} & \multicolumn{1}{c}{ Statistic } & Teaching Field \\
\cline { 3 - 4 } & \% Partly certified & $12.6 \%$ & General Education \\
\hline Main Teaching Assignment $^{\mathrm{a}}$ & Standard error \% & $0.8 \%$ & $10.5 \%$ \\
& \% Partly certified & $11.6 \%$ & $0.2 \%$ \\
Any Teaching Assignment & Standard error \% & $0.7 \%$ & $9.9 \%$ \\
Within Cognate Area $^{\mathrm{b}}$ & \% Partly certified & $9.0 \%$ & $0.2 \%$ \\
Any Teaching Assignment $^{\mathrm{c}}$ & Standard error \% & $0.6 \%$ & $8.3 \%$ \\
& National Estimate & 330,297 & $0.2 \%$ \\
Total Teachers & Sample $(N)$ & 4,919 & $2,268,103$ \\
& & & 39,977 \\
\hline
\end{tabular}

Note. Data from the 1999-2000 Schools and Staffing Surveys, National Center for Education Statistics, USDE. Nationally weighted percentages of partly certified teachers based on the total number of teachers. Standard error $\%=$ standard error of the partly certified percentages. National estimate = nationally weighted estimate of the total number of public school teachers in the U.S.

${ }^{a}$ For teachers certified in their main teaching assignment, certification by field $\chi^{2}(1, N=44,896)=20.9, p<.001$. ${ }^{b}$ For teachers certified in any teaching assignment within their cognate area, certification by field $\chi^{2}(1, N=44,896)=13.9$, $p<.001$. 'For teachers certified in any teaching assignment, certification by field $\chi^{2}(1, N=44,896)=2.5, p<$ ns.

during this recent 8-year period, the number of additional fully certified SETs needed to replace the partly certified SETs almost doubled from 25,000 to 49,000 .

To satisfy the demand for teachers to fill open positions, special education hired into its teaching force a cohort of entering teachers that was seriously undercertified (44.4\% partly certified), and much more so than in general education $(31.2 \%$ partly certified). In contrast, the lowest level of shortage of fully certified teachers (about 7.5\%) was among established teachers in both special and general education (i.e., continuing teachers who became established in the same main teaching assignment in the same school for 2 years).

All categories of entering teachers exacerbated the overall shortage of fully certified SETs (12.5\% of all SETs in 1999-2000) instead of providing a partial solution to the shortage problem. None of the sources of entering teacher supply yielded a high percentage of fully certified SETs. Of these, the best sources of fully certified entering SETs were reentering experienced teachers (26.8\% of whom were partly certified), private school migrants $(32.9 \%$ of whom were partly certified), and recent graduates with extensive teacher preparation (35.9\% of whom were partly certified). Two sources produced virtually no fully certified teachers (first-time teachers with only some teacher preparation or with no teacher preparation).

The reason why $46.9 \%$ of first-time entering SETs with extensive teacher preparation were only partly certified cannot be attributed mainly to poor preparation by teacher education in special education. Instead, over $25 \%$ of such entering SETs had completed teacher preparation with a degree major in a field other than special education. When the certification status of first-time SETs with extensive teacher preparation in special education was compared with that of first-time GETs with extensive teacher preparation in general education, the levels of part certification were similar (28.5\% for SETs; $24.9 \%$ for GETs). These facts strongly suggest a serious deficiency in the numbers of graduates produced by teacher preparation programs in special education. Certainly, if fully certified applicants were available to fill open positions, they would be hired.

Put plainly, there is a serious shortage in the supply of fully certified first-time SETs. To confront this reality in hiring teachers for its class- 
TABLE 5

Percentage of First-Time Special and General Education Teachers Who Were Partly Certified: National Estimates by Category of Teaching Assignment, 1999-2000 School Year

\begin{tabular}{llcc}
\hline \multirow{2}{*}{$\begin{array}{l}\text { Certification by } \\
\text { Teaching Assignment }\end{array}$} & \multicolumn{1}{c}{ Statistic } & Special Education & General Education \\
\cline { 3 - 4 } Main Teaching Assignment $^{\mathrm{a}}$ & \% Partly certified & $60.2 \%$ & $38.1 \%$ \\
& Standard error \% & $5.6 \%$ & $1.8 \%$ \\
Any Teaching Assignment $_{\text {Within Cognate Area }}^{\mathrm{b}}$ & \% Partly certified & $56.5 \%$ & $36.6 \%$ \\
Any Teaching Assignment $^{\mathrm{c}}$ & Standard error \% & $6.1 \%$ & $1.8 \%$ \\
& \% Partly certified & $51.9 \%$ & $33.2 \%$ \\
Total First-Time Teachers & Standard error \% & $6.1 \%$ & $1.9 \%$ \\
& National Estimate & 13,292 & 113,907 \\
& Sample (N) & 209 & 1,950 \\
\hline
\end{tabular}

Note. Data from the 1999-2000 Schools and Staffing Surveys, National Center for Education Statistics, USDE.

Nationally weighted percentages of partly certified teachers based on the total number of teachers. Standard error

$\%=$ standard error of the partly certified percentages. National estimate = nationally weighted estimate of the total number of first-time public school teachers in the U.S.

${ }^{a}$ For teachers certified in their main teaching assignment, certification by field $\chi^{2}(1, N=2,159)=41.1, p<.001$. ${ }^{b}$ For teachers certified in any teaching assignment within their teaching field, certification by field $\chi^{2}(1, N=2,159)=33.7$,

$\mathrm{p}<.001$. ${ }^{\mathrm{F}}$ For first-time teachers certified in any teaching assignment, certification by field $\chi^{2}(1, N=2,159)=31.0$, $p<.001$.

rooms, special education has had to hire over $50 \%$ of its first-time teachers from out of field or without extensive teacher preparation. Thus, the shortage of fully certified teachers in special education keeps growing over time due to inadequate supply of fully certified teachers to fill the demand.

Furthermore, the shortage of teachers who are fully certified in main teaching assignments in special education (12.5\% of all SETs) is not principally due to misassignment of SETs who are fully certified in some other assignment or due to influx of teachers who are fully certified in general education. Instead, our results show that $9.0 \%$ of all SETs were not fully certified in any teaching assignment.

The shortage of fully certified SETs is a problem that has been chronic and is somewhat greater than in general education. Moreover, the magnitude of this problem has increased as (a) the production of degree graduates in special education slowly declined since 1998 (Cook \& Boe, 2004), (b) the production of special education teachers by alternative routes to certification (ARC) increased (Rosenberg \& Sindelar, 2005), and (c) the number of teaching positions in spe- cial education grew by $20 \%$ during a recent 8 year period.

Concurrently, the No Child Left Behind Act has increased requirements for teacher qualification. NCLB requires that new teachers in core academic areas be highly qualified beginning with year 2002-2003, and that all teachers in core academic areas be highly qualified by 2005-2006 (NCLB, 2002). This includes most SETs, and full certification is one of the components of a HQT as required by NCLB. In this and other respects, the demand for more fully certified teachers is increasing, yet the response from the field of education has clearly been inadequate.

While this situation is recognized in the special education field, these results quantify the magnitude of the problem in subtle detail with the most recent national data. They also suggest solutions for (a) increasing the supply of qualified entering teachers, and (b) improving the qualifications of continuing teachers.

For example, the decline in the production of degree graduates from teacher preparation programs in special education should not only be reversed, but production should be increased 
dramatically to improve the pool of qualified applicants. In addition, recruiting from the reserve pool of experienced teachers and among private school teachers, instead of among teachers with only some or no preparation, will improve the level of certification of new hires.

Although increasing the supply of newly minted teachers with majors in areas of special education is critical to addressing the shortage of fully certified SETs, this should not diminish other constructive actions-especially upgrading the qualifications of employed SETs through professional development, optimizing the assignment of teachers to positions for which they are fully certified, and reducing the transfer of fully certified SETs to general education. Some beginning teachers may satisfy all requirements for full certification shortly after entering the teaching force by passing an examination or completing a final course requirement, or by submitting necessary paperwork from one state to another. Many other continuing teachers improve their qualifications by earning degrees from teacher preparation programs while employed as teachers (Boe, Cook, Paulsen, Barkanic, \& Leow, 1999; Cook \& Boe, 2004), although others may complete teacher preparation programs leading to certification but not to degrees. Professional development programs and ARC are also helpful in improving teacher credentials (Rosenberg \& Sindelar, 2005). However, we do not know the extent to which partly certified teachers attain full certification in their main teaching assignments while employed as teachers. Research involving NCES's Teacher Followup Survey of 2000-2001, administered 1 year following the 1999-2000 SASS, may cast new light on the issue. Nonetheless, the annual improvement in qualifications by employed teachers has been far from sufficient to reduce the chronic shortage of fully certified SETs.

Finally, steps need to be taken to make a teaching career more appealing in order to improve retention of qualified SETs. In spite of the conclusion by the National Commission on Teaching and America's Future (2003) that this strategy holds the greatest promise of solving the teacher shortage problem, others have produced quantitative evidence and reasons why there is but modest potential for improving the retention of qualified teachers under present working condi- tions and compensation policies (Boe, Bobbitt, \& Cook, 1997).

Still, substantially improving the working conditions and professional status of SETs can be expected to have a generalized beneficial effect by increasing the number of individuals entering teacher preparation programs, improving the recruitment of well prepared SETs, and enhancing the retention of fully certified SETs.

With respect to the shortage of qualified teachers, further research is needed to assess and compare the qualifications of teachers who complete each of the two major types of preparation (traditional university-based degree programs and ARC programs), and to determine the extent to which each type impacts on the shortage of fully certified teachers. It is not possible to identify and analyze with national data first-time teachers who complete each type of program from PSTQ. National level multivariate research is needed on the extent to which various types of teacher preparation and professional development programs produce SETs who are qualified in multiple dimensions and satisfy NCLB standards for a HQT.

Further, much more needs to be known about teacher turnover and retention as a function of teacher qualifications. For example, Boe, Barkanic, and Leow (1999) found that 35\% of teachers that moved between schools, or left teaching altogether, did so involuntarily. Of the $65 \%$ that moved or left voluntarily, those who were partly certified, out-of-field, and least qualified were more likely to move and leave than those who were the more qualified. Boe et al. (1998b) also found the same results for teachers who switched between eight broad teaching fields (such as special education, elementary education, science education, etc.). Thus, some turnover is constructive when unqualified teachers vacate a position and when teachers switch to positions for which they are more qualified (Boe et al., 1999). The management task is to create and engineer incentives to improve the retention of teachers who are qualified in the positions they hold, while either upgrading those who are not qualified, or encouraging their turnover. 


\section{R E F E R E C E S}

American Association for Employment in Education. (1999). Educator supply and demand in the United States: 1999 Research report: Columbus, OH: Author.

Boe, E. E., Barkanic, G., \& Leow, C. S. (1999). Retention and attrition of teachers at the school level: National trends and predictors (Data Analysis Rep. No. 1999DAR1). Philadelphia: University of Pennsylvania, Graduate School of Education, Center for Research and Evaluation in Social Policy.

Boe, E. E., Bobbitt, S. A., \& Cook, L. H. (1997). Whither didst thou go? Retention, reassignment, migration, and attrition of special and general education teachers from a national perspective. The Journal of Special Education, 30, 371-389.

Boe, E. E., Bobbitt, S. A., Cook, L. H., \& Barkanic, G. (1998). National trends in teacher supply and turnover for special and general education (Data Analysis Rep. No. 1998-DAR1). Philadelphia: University of Pennsylvania, Graduate School of Education, Center for Research and Evaluation in Social Policy.

Boe, E. E., Bobbitt, S. A., Cook, L. H., Barkanic, G., \& Maislin, G. (1998a). Sources of supply of teachers for eight cognate areas: National trends and predictors (Data Analysis Rep. No. 1998-DAR2). Philadelphia: University of Pennsylvania, Graduate School of Education, Center for Research and Evaluation in Social Policy.

Boe, E. E., Bobbitt, S. A., Cook, L. H., Barkanic, G., \& Maislin, G. (1998b). Teacher turnover in eight cognate areas: National trends and predictors (Data Analysis Rep. No. 1998-DAR3). Philadelphia: University of Pennsylvania, Graduate School of Education, Center for Research and Evaluation in Social Policy.

Boe, E. E., Cook, L. H., Bobbitt, S. A., \& Terhanian, G. (1998). The shortage of fully certified teachers in special and general education. Teacher Education and Special Education, 21(1), 1-21.

Boe, E. E., Cook, L. H., Paulsen, C. A., Barkanic, G., \& Leow, C. S. (1999). Productivity of teacher preparation programs: Surplus or shortage in quantity and quality of degree graduates (Data Analysis Rep. No. 1999DAR2). Philadelphia: University of Pennsylvania, Graduate School of Education, Center for Research and Evaluation in Social Policy.

Boe, E. E., Shin, S., \& Cook, L. H. (2005). Does teacher preparation matter for beginning teachers in either special or general education? (Research Rep. 2005TSD3). Philadelphia: University of Pennsylvania, Graduate School of Education, Center for Research and Evaluation in Social Policy.
Carlson, E., Lee, H., Schroll, K., Klein, S. Willing, S. (2002). Final report of the study of personnel needs in special education. Washington, DC: Office of Special Education Programs, U.S. Department of Education.

Cook, L. H., \& Boe, E. E. (2004). From whence didst thou come: National trends in the sources of supply of teachers in special and general education (Research Rep. 2004-TSD1). Philadelphia: University of Pennsylvania, Graduate School of Education, Center for Research and Evaluation in Social Policy.

Darling-Hammond, L. (2001). The research and rhetoric on teacher certification: A response to "Teacher certification reconsidered.” Washington, DC: National Commission on Teaching and America's Future.

ERIC Clearinghouse on Disabilities and Gifted Education. (2001). Conditions of teaching children with exceptional learning needs: The Bright Futures report (ERIC EC Digest \#E613). Arlington, VA: Author.

Henke, R. R., Choy, S. P., Chen, X., Geis, S., Alt, M. N., \& Broughman, S. P. (1997). America's teachers: Profile of a profession, 1993-94. Washington, DC: National Center for Education Statistics, US Department of Education.

Ingersoll, R. M. (2002). Out-of-field teaching, educational inequality, and the organization of schools: An exploratory analysis (A Research Report). Seattle: University of Washington, Center for the Study of Teaching and Policy.

Lauritzen, P. (1999). Supply and demand of educational personnel for Wisconsin Public Schools: An examination of data trends. Whitewater, WI: Wisconsin Educator Supply and Demand Project.

McLeskey, J., Tyler, N. C., \& Flippin, S. S. (2004). The supply and demand for special education teachers: A review of research regarding the chronic shortage of special education teachers. Journal of Special Education, 38(1), 5-21.

National Association of State Directors of Teacher Education and Certification. (2003). The NASDTEC manual on the preparation and certification of educational personnel 2003 (8th ed.). Sacramento, CA: School Services of California.

National Commission on Teaching and America's Future. (2003). No dream denied: A pledge to America's children. New York: The National Commission on Teaching and America's Future.

No Child Left Behind Act of 2001, Public L. No. 107110, Title IX, Part A, \$\$ 9101(23) and 1119(a)(3) (2002). 
Nougaret, A. A., Scruggs, T. E., \& Mastropieri, M. A. (2005). Does teacher education produce better special education teachers? Exceptional Children, 71, 217-229.

Office of Special Education Programs. (1998). Twentieth annual report to Congress on the implementation of the Individuals with Disabilities Education Act. Washington, DC: U.S. Department of Education.

Office of Special Education Programs. (2004). Twentysixth annual report to Congress on the implementation of the Individuals with Disabilities Education Act. Washington, DC: U.S. Department of Education.

Recruiting New Teachers, Inc. (2000). The urban teacher challenge: Teacher supply and demand in the Great City Schools. Belmont, MA: Author.

Rosenberg, M. S., \& Sindelar, P. T. (2005). The proliferation of alternative routes to certification in special education: A critical review of the literature. Journal of Special Education, 39(2), 117-127.

Southern Regional Education Board. (2001). Teacher supply and demand in Tennessee. Atlanta, GA: Author.

Tourkin, S. C., Pugh, K. W,, Fondelier, S. E., Parmer, R. J., Cole, C., Jackson, B., et al. (2004). 1999-2000 Schools and Staffing Survey (SASS) data file user's manual (NCES 2004-303). Washington, DC: U.S. Department of Education.

U.S. Department of Education. (2003). Meeting the highly qualified teachers challenge: The Secretary's second annual report on teacher quality. Washington, DC: U.S. Department of Education.

Walsh, K. (2001). Teacher certification reconsidered: Stumbling for quality. Baltimore, MD: The Abell Foundation.
Wayne, A. J., \& Youngs, P. (2003). Teacher characteristics and student achievement gains: A Review. Review of Educational Research, 73(1), 89-122.

Westat, Inc. (2002). WesVar (Version 4.2) [Computer software]. Rockville, MD: Author.

\section{ABOUTTHE AUTHORS}

erling e. boe (CEC PA Federation), Professor, Graduate School of Education, University of Pennsylvania, Philadelphia; LYNNE H. CoOK (CEC CA Federation), Dean, College of Education, California State University, Dominguez Hills.

Address correspondence to Erling E. Boe, Graduate School of Education, University of Pennsylvania, 3700 Walnut Street, Philadelphia, PA 19104-6216. (e-mail: boe@pobox.upenn.edu)

Support for this research was provided by a grant (Award Number H0324C020002) from the U.S. Department of Education's Research and Innovation to Improve Services and Results for Children with Disabilities Program (Field Initiated Research Projects, CFDA Number: 84-024C). Opinions expressed do not necessarily reflect the position of the U.S. Department of Education, and no endorsement should be inferred.

Manuscript received December 2004; accepted April 2005. 